\title{
The United States and Mongolia Relations: The Underrated Partnership
}

\author{
Sanchana Srivastava ${ }^{1}$
}

\begin{abstract}
The United States has, in recent years, touted the accomplishment of Mongolian democracy as a positive example to other nations in the region. The shift from Socialism to democracy on the part of the Mongolians has dominated both academic discourse and political speeches alike on the growing friendship between these two countries. This article argues, however, that the growing relationship between the United States and Mongolia is one based on practical benefits to both parties instead of the ideals of liberal democracy. Hence, US-Mongolia relations are based in realpolitik, not ideology. Stronger US-Mongolia relations are, and should be, based on the practical benefits each will gain from the partnership. Mongolia's benefits encompass the preservation of national independence, regional and global security, and increased domestic economic growth and infrastructure. For the US, the benefits concern Mongolia's strategic geopolitical position between Russia and China and its implications for US strategy in the region, Mongolia's access to North Korea, and finding a friend in hostile territory in the USled war on international terrorism.
\end{abstract}

Keywords: United States, Underrated partnership, Mongolia, Realpolitik, Democracy

\section{Introduction}

The political mob of 1 July 2008 distinctly delineated that liberal majority rule system in Mongolia actually stays unsteady. Nonetheless, the US has over and over piled acclaim upon Mongolia's creating majority rule government and has "remunerated" Mongolia with more grounded political and financial relations. Much consideration has so far been given to the examination of expanded US - Mongolia relations with regards to building vote based systems in the Upper east and local Asian districts, as Mongolia advantageously falls under both

\footnotetext{
${ }^{1}$ Sanchana Srivasatava is pursuing her Masters in International Relations at Central University of Jharkhand, Ranchi, India.
} 
geographic regions. In any case, an examination dependent on the spreading philosophy of the majority rules system as a main impetus of the expanding cooperation among Mongolia and the US is lacking, essentially because of the simple reality that Mongolia doesn't have a working liberal popular government right now. Defilement is as yet wild all through Mongolian common society, which thus stifles regular citizen interest in government and society overall. Laws drafted in accordance with vote based changes, albeit a difference from Mongolia's communist period, are not what numerous in the US consider viable with majority rules system. The legal executive remaining parts got up to speed in political defilement and its viability is as yet under question. This was crucially obvious after the 2008 mobs in which many "political dissenters" were held for quite a long time without legal executive activity. The Mongolian economy is as yet immature and defilement torment the two biggest enterprises of banking and mining, just as the traditions framework. More grounded US-Mongolia relations are, and ought to be, founded on the pragmatic benefits each will acquire from the association. Mongolia's advantages incorporate the safeguarding of public freedom, local and worldwide security, and expanded homegrown financial development and framework. For the US, the advantages concern Mongolia's key international situation among Russia and China and its suggestions for US system in the locale, Mongolia's admittance to North Korea, and finding a companion in an unfriendly area in the US-drove battle on worldwide illegal intimidation. Mongolia's choice to democratize itself following the fall of the Soviet Association has little to do with the improvement of US-Mongolia relations in the course of the last decade and a half. As referenced before, fusing the US into the North Asian provincial international system was engaged as far back as 1919, under the tyrant religious government of Bogd Khan. It very well may be contended that the fall of the Soviet Association in 1992 was simply the equivalent "reset" button that was pushed toward the finish of the Qing tradition in 1911, which left Mongolia in political limbo.

\section{Historical analysis of U.S.-Mongolia Relations}

The United States established diplomatic relations with Mongolia in 1987, and Mongolian leaders describe the United States as Mongolia's most important "third neighbor"-countries that do not border Mongolia but have close relations with it. Polling indicates Mongolian perceptions of the United States are largely positive. Mongolia's relations with its former patron Russia remain close, and many Mongolians regard Russia with some affection. At the same time, they remain wary of China, their largest economic partner. Mongolia's official 
relations with China largely have been amicable, with the exception of periods of tension and pressure from Beijing following visits to Mongolia, a traditionally Tibetan Buddhist country, by the Dalai Lama, the exiled Tibetan spiritual leader whom the PRC government asserts aims to split Tibet from China

\section{Mongolia's Interest}

The desire for Mongolia to improve relations between it and the US revolve around three key components: political independence, regional and global security, and economic growth.

\section{Political independence}

First and foremost, Mongolia views its growing relations with the United States as confirmation of its status as an equal member of the international community. Considering Mongolia's history of Chinese rule and Russian the most critical element in Mongolia-United States is the belief of Mongolia's “1/3 neighbor” overseas coverage. As each Russia and China have tussled over Mongol territory for over 4 hundred years, with each exercise brilliant influence (if now no longer direct rule) over it at distinctive times, another "neighbor" or out of doors energy is visible as crucial in balancing the have an impact on of each Russia and China and preserving Mongolian independence. Although the " $1 / 3$ neighbor" coverage is basically open to all international locations who desire to broaden family members with Mongolia, the Mongolian authorities perspectives relationship the United States as its essential priority. The overarching topic that dominates US-Mongolia family members is really keeping Mongolian independence. The US is engaged on this thru numerous means, the primary of that is placing itself into the conventional north Asian association of Russia-China-Mongolia family members. In line with each Mongolia's desires and US self-interest, the United States-Mongolia partnership has improved the country wide members on this framework from 3 to 4 . It is the desire of Mongolia that this in flip will regulate the dynamics of the location, in order that Mongolia will circulate from being certain through Russia-China geopolitics to turning into a completely impartial member of the location and worldwide society. This may be completed specifically through diplomatic avenues.

\section{Regional participation}


In line with the above assumption, Mongolia views US involvement in Northeast Asia as essential to its participation in regional community building into which Mongolia has invested much of its foreign policy efforts. To put it bluntly, Mongolia has been, and remains, as an afterthought in these negotiations due to its perceived insignificance regarding what it can offer the region politically and economically. Although Mongolia's inclusion in any type of formal, comprehensive region-wide community building is not in question, Mongolia would like to play a larger role in these negotiations in order to solidify its position as an independent, equal nation-state. Subsequently Mongolia hopes to be incorporated into these negotiations by ensuring US support for its inclusion into any talks that may arise.

\section{US military support}

The buildup of Mongolia's military is without a doubt based on maintaining its independence. In the past Mongolia's military has been developed and maintained largely by either Soviet Russia or China. Mongolia does not wish to repeat this scenario for fear of over-reliance on its powerful neighbors, and their possible political and military coercion; so it looks to the US for support in developing Mongolia's military. As Mongolia does not share a border with the US, and has no history of US interference, it can comfortably develop a bilateral alliance with this geographically distant super power. The fear of a Chinese invasion from the south to absorb the Mongol territory previously under Chinese rule, however, has decreased dramatically since the mid to late 1980's. Nonetheless, this suspicion still lingers, given that China's growth is disproportionately high compared with other nations of the region, especially compared to Russia; and suspicion of the Chinese is an enduring theme among Mongolia's politicians and citizenry. Of greater importance to Mongolia at this time is the support of the US in building and training the Mongolian military to participate in international peace-keeping operations. Mongolia views contributing to peace-keeping forces as "a foot in the door" towards greater international participation, and thus far has contributed over 700 troops to the US-led operations in Afghanistan and Iraq. In return, the Mongolian military has benefited a great deal from US human resources, as well as monetary and technical support. The US has afforded Mongolian officers, citizens, and Foreign Service personnel the opportunity to attend military academic and training institutions across the US; engage in multiple training programs alongside US military personnel; and be given large amounts of technical support and upgrades. Moreover, as Mongolia is geographically situated at the intersection of East and Central Asia, the threat of international terrorism impacting Mongolia is real. Mongolia's 
western populations are made up of Muslim Kazaks whose ethnic and religious affiliations transcend Mongolia's borders. A well-equipped Mongolian military is seen as essential to address possible insecurities that may arise in Mongolia's western areas. As Mongolia and China share this common threat of growing Muslim extremism in their western territories, a competent Mongolian military able to handle the threat of terrorism may help redress the balance in Mongolia-China relations.

\section{Economic independence}

It is seen by many in Mongolia that economic independence promotes political independence. The assistance of a major economic power besides Russia and China is essential in achieving this independence. Mongol history witnessed Qing China impose Mongolian obedience through monetary support, as well as the accumulation of massive debt on the part of Mongolian tribal leaders and the Buddhist theocracy in the eighteenth and nineteenth centuries. In contrast, the Soviet Union bankrolled virtually 80 percent of the Mongolian economy during the 70 years of Soviet influence over Mongolia in the twentieth century. As the urban populations of Mongolia increase their standard of living, Mongolian domestic politics are under more pressure to liberalize the economy. Mongolia today is the only World Trade Organization member nation that does not have a bilateral Free Trade Agreement (FTA) with any other nation. This is set to change with Mongolia's current strategy of forming an FTA with the US. Currently the US considers an FTA with Mongolia as unjustifiable on economic grounds alone, although the US is not ruling it out completely. Finally, where many of the former Soviet republics, such as the Ukraine, Georgia, Azerbaijan, and Armenia, have fostered closer ties with the European Union (culminating in the "Eastern Partnership"), Mongolia, although seeking to democratize, has no such convenient body to turn to. Considering the international clout of the US, the Mongolian government recognizes the importance of closer economic US ties in its pursuit of a more independent and economically stable Mongolia.

\section{The United States' Interest}

This section argues that the primary goal of the US in engaging Mongolia lies in Mongolia's unique position in the region and its possible benefits to US strategic interests. Mongolia's strategic geographical position.

\section{Mongolia's strategic geographical position}


The US views a strong relationship with Mongolia as beneficial to its overall Asia strategic plan, especially due to Mongolia's geographical position between Russia and China. From the end of World War II until the fall of the Soviet Union in 1992, the US's Asia strategy was based on an alliance system, often referred to as the "hub-and-spoke" model. This arrangement was essentially made up of a few strategically important allies that entered into bilateral defense relationships with the US. This has, for the most part, kept conflict in the region subdued in comparison to the era before World War II. The Chinese government generally saw US troops based in Japan as beneficial, as a large US military presence in Japan prevented a re-occurrence of imperial ambitions by the Japanese on the Asian continent. A US presence in Asia allowed China to undertake economic reforms to modernize with no real military threat, and South Korea viewed US troops on its side of the Demilitarized Zone as necessary for peace on the Korean Peninsula. However, although US soldiers did not leave either Japan or South Korea, the US strategy in Asia following the Cold War shifted from a dominant focus on security to a mixture of security and economic issues. This was evident during the Clinton Administration's China policy, where it chose to engage China economically instead of containing or countering its rapid rise either regionally or globally. Since that time, China has argued that its rise is peaceful and has, to the surprise of many, embraced multilateralism as a core foreign policy. However, China still asserts its sovereignty over ethnic minority areas such as Tibet, Xinjiang (the Muslim Uighur population), and Inner Mongolia. The ethnic unrest seen in Tibet has not been contained and Xinjiang has also recently developed into an ethnic/religious hotspot within China's borders. This unrest could possibly spill over into Inner Mongolia as well. Islamic fundamentalism is already a real concern in Xinjiang, and even though pan-Mongolianism is subdued, it is still present in Inner Mongolia. One significant factor in China's rise is whether China can contain these ethnic "domestic" issues. Given their ethnic nature, these domestic issues could put China's economic growth in the region on a collision course with the national interests of some or all of its Central Asian neighbors, given that these ethnic issues inevitably transcend modern nation-state borders. As US interests are embedded in the Central Asian region, where the fi the former Soviet countries of Kazakhstan, Kyrgyzstan, Turkmenistan, Tajikistan, and Uzbekistan have been instrumental in the US-led "War on Terror" in Afghanistan and Iraq, conflict between the US and China is not out of the question. If China is coerced to change the status quo of the Central Asian region and engage with it more forcefully due to domestic issues spilling over China's borders, US interests in the region will inevitably be at risk. A conflict of interest is likely between China and the US over large deposits of oil, 
natural gas, uranium, and gold. As these resources are located in the Central Asia region, the US views Mongolia as a convenient ally in its relations with China. A US-Mongolia military partnership could relieve unnecessary pressure if a conflict of interest between the US and China arose in Central Asia. Mongolia's location at the intersection of Northeast and Central Asia could provide a diffusing mechanism for the US military in the event of a possible confrontation with China. Furthermore, a US presence in Mongolia would ensure US influence in the region by in effect coercing China, North Korea, and Russia to include the US in any regional security or economic dialogue. The US already has a firm foothold in the region with military bases in Japan and South Korea. However, Mongolia's efforts to establish closer US relations is incredibly convenient, as it pushes the US presence further to the north and northwest, inserting itself in what has traditionally been a solid block of exclusively Russian and Chinese negotiated territory. As with US-China relations, US-Russia relations in Central Asia highlight for the US the significance of an alliance with Mongolia. In early February 2009, Kyrgyzstan announced its plans to close a strategic US air base that has been critical to US missions into Afghanistan. Many observers see this as a decision influenced by Russia to squeeze the US out of Central Asia. Upon the announcement by Kyrgyzstan, Russia immediately offered its support for the US to use Russian bases for its Afghan operations, a move which would place US actions in Central Asia under tighter scrutiny from Russia's watchful eye. Although the US negotiated with the Kyrgyzstan government effectively and avoided this roadblock, the US will need to give up increasingly more negotiating power to ensure its place in the region. As Russia once again exerts itself internationally, moves like this cause the US to seek other options. Mongolia, with one foot in Central Asia and the other foot outside the region, provides an opportune alternative. Although Russia views Mongolia directly within its sphere of influence, as it does the former Soviet Central Asian nations, Russia's grip on Mongolia has softened since Gorbachev's Valdiviostock speech in 1986 and the subsequent fall of the Soviet Union in 1992. Since that time, Mongolia's position between the Soviet Union and China was vital in rebuilding Russia, as Russia held on to virtually all of Siberia. Due to a diminished threat from China, coupled with the domestic push by Mongolia to distance itself from Russia, Russia has backed away from Mongolia considerably since then. For the US, Mongolia's decision to seek a "third neighbor" is strategically in line with US foreign policy interests.

\section{North Korea relations}


The North Korean nuclear issue is of vital concern to the US in the Northeast Asian region. Maintaining the status quo that emerged after the Korean War is vital to maintaining a US presence in the region. Although Mongolia's declaration of itself as a "Nuclear Free Territorial Zone" was initially intended as a reaction to its position between the two nuclear powers of Russia and China and its experience during the Sino-Soviet conflict, it does hold positive implications for the US in its mediation with North Korea. As Endicott (2005: 23) says:

I regret that we have not been able to witness a 7-Party Talks in Beijing where Mongolia could play a significant facilitator role in its ongoing quest to help improve the security of the region.

Mongolia has also been instrumental in "Track II" negotiations In July 1986, Soviet Head of State Gorbachev gave a speech in Vladivostok outlining the Soviet Union's new Asia policy and positive re-engagement with China. This had implications on Mongolia's relations with both China and the West, as China had established relations with the United States in 1979.

\section{Combating international terrorism}

The US views Mongolia as a key player in its fight against the spread of international terrorism. To date, Mongolia has contributed over 700 of its military personnel to the US-led operations in Afghanistan and Iraq. The ratio of servicemen who served in Iraq and Afghanistan to Mongolia's total population (which is roughly 2.7 million) ranks Mongolia's contribution to the wars in Afghanistan and Iraq higher than those of Japan and South Korea; both of which are established allies of the US. Mongolia's strategic location gives closer access to potential terrorist "hot spots," such as Central Asia and Northwestern China (Xinjiang). A stable and independent Mongolia is of the utmost importance to the US, whether it is a democracy or an authoritarian theocracy, as it was at the start of the twentieth century. What is our important to the US is that Mongolia gains and maintains its political distance

\section{Conclusion}

The mutual interest of both the countries have been emphasized upon different aspects. On January 27, 2017, Mongolia and the United States celebrated the 30th anniversary of their diplomatic relations at the Embassy of Mongolia in Washington DC. While the two countries have gone through different phases of development, reform, and economic booms and crises 
in their domestic environments, the achievements in their bilateral ties were rooted in shared principles and values. During the past 30 years, Mongolia and the United States have augmented relations through diplomatic means in the political, economic, social, and military spheres. Mongolia made a few attempts to engage the United States even while still under the heavy influence of Russia and China. Boosting ties with Mongolia could be a way for the US to show China it has found an alternative country that can meet its rare-earth demands. This would reduce US reliance on China in this regard. 


\section{References}

Auslin, Michael. 2008. "A Third Neighbor Strategy for Asia," Asian Outlook. American Enterprise Institute for Public Policy Research (3 October), [online] http://www.aei.org/outlook/28731 (accessed on 13 December 2008).

Batbayar, Ts. 2006. "Mongolia's Post-Soviet Identity and New External Environment."Mongolica, An International Annual of Mongol Studies, 17(38): 187-195.

Batbayar, Tsedendamba. 2003. "Foreign Policy and Domestic Reform in Mongolia." Central Asian Survey 22.1 (March): 45-59.

Batbayar, Tsedendambyn. 1999. "Mongolian Perspectives on Northeast Asian Regional Development.'Pp 207-223 in Politics and Economics in Northeast Asia: Nationalism and Regionalism in Contention. Bloomsburg: MacMillan Press.

Batchimeg, Migeddorg. 2005. "Mongolia-China Relations and its Implications on MongoliaUS Relations.” Pp 46-58 in A Comprehensive US-Mongolia Partnership: Challenges and Opportunities. Regional Security Issues and Mongolia, The Institute for Strategic Studies, Vol. XXVI/MMIV. Proceedings of the Bilateral Conference (28 February - 1 March 2005).

Campi, Alicia Jean. 1987. The Political Relationship between the United States and Outer Mongolia, 1915-1927: Kalgan Consular Records. Bloomington: Indiana University.

Endicott, Dr. John E. 2005. "Mongolia-US Comprehensive Relationship." Pp 18-30 in A Comprehensive US-Mongolia Partnership: Challenges and Opportunities. Regional Security Issues and Mongolia, The Institute for Strategic Studies, Vol. XXVI/MMIV. Proceedings of the Bilateral Conference (28 February - 1 March 2005).

Gilberg, Rolf and Jan-Olof Svantesson. 1996. "The Mongols, Their Land and History," in Mongolia in Transition: Old Patterns, New Challenges, Ole Bruun and Ole Odgaard (eds), Nordic Institute of Asian Studies. Great Britain: Curzon Press.

Gombo, Enebish. 2007. Interviewed by Ron Porter, 4 August. Green, Elizabeth E. 1986. "China and Mongolia: Recurring Trends and Prospects for Change," Asian Survey 26.12 (December): 1337-1363.

Janhunen, Juha. 2006. "Mongolia and China: Geopolitical Implications of the Unequal Relationship," in Mongolica, An International Annual of Mongol Studies, Vol. 17 (38): 213219.

Kennedy, William. 2008. “After Six Weeks, Mongolian Lawmaker, Demonstrator Posts Bail." [online] http://ubpost.mongolnews.mn/index.php?option=com_content\& task=view\&id=2139\&Itemid=37 The UB Post Online [Ulaanbaatar], 14 August (accessed on 26 January 2009).

Khirghis, Munkh-Ochir, D. 2005. "Mongolia-US Comprehensive Partnership: Opportunities and Challenges." Pp 31-45 in A Comprehensive US-Mongolia Partnership: Challenges and Opportunities, Regional Security Issues and Mongolia. The Institute for Strategic Studies, Vol. XXVI/MMIV. Proceedings of the Bilateral Conference (28 February - 1 March).

La Porta, Ambassador Alphonse F. 2005. "Free Trade Agreement between Mongolia and US: Illusion or Reality? (The US View)." Pp 60-65 in A Comprehensive US-Mongolia Partnership: Challenges and Opportunities. Regional Security Issues and Mongolia, The Institute for Strategic Studies, Vol. XXVI/MMIV. Proceedings of the Bilateral Conference (28 February 1 March 2005). 